\title{
Pathological Mechanisms and Potential Therapeutic Targets of Pulmonary Arterial Hypertension: A Review
}

\author{
Ying Xiao', Pei-Pei Chen", Rui-Lin Zhou ${ }^{2}$, Yang Zhang1, Zhuang Tian ${ }^{1 *}$, Shu-Yang Zhang ${ }^{*}$ \\ ${ }^{1}$ Department of Cardiology, Peking Union Medical College Hospital, Chinese Academy of Medical Sciences \\ and Peking Union Medical College, Beijing, China \\ ${ }^{2}$ School of Medicine, Tsinghua University, Beijing 100084, China
}

[Received October 19, 2019; Revised January 10, 2020; Accepted January 11, 2020]

\begin{abstract}
Pulmonary arterial hypertension (PAH) is a progressive cardiovascular disease characterized by pulmonary vasculature reconstruction and right ventricular dysfunction. The mortality rate of PAH remains high, although multiple therapeutic strategies have been implemented in clinical practice. These drugs mainly target the endothelin-1, prostacyclin and nitric oxide pathways. Management for PAH treatment includes improving symptoms, enhancing quality of life, and extending survival rate. Existing drugs developed to treat the disease have resulted in enormous economic and healthcare liabilities. The estimated cost for advanced PAH has exceeded \$200,000 per year. The pathogenesis of PAH is associated with numerous molecular processes. It mainly includes germline mutation, inflammation, dysfunction of pulmonary arterial endothelial cells, epigenetic modifications, DNA damage, metabolic dysfunction, sex hormone imbalance, and oxidative stress, among others. Findings based on the pathobiology of PAH may have promising therapeutic outcomes. Hence, faced with the challenges of increasing healthcare demands, in this review, we attempted to explore the pathological mechanisms and alternative therapeutic targets, including other auxiliary devices or interventional therapies, in PAH. The article will discuss the potential therapies of PAH in detail, which may require further investigation before implementation.
\end{abstract}

Key words: pulmonary arterial hypertension; right ventricular dysfunction; hemodynamics; therapy advances

\section{Introduction}

Pulmonary hypertension (PH) is a cardio-respiratory disease characterized by a resting mean pulmonary arterial pressure (mPAP) $\geq 25 \mathrm{mmHg}$, as measured by a right heart catheter (RHC). The World Health Organization (WHO) has grouped $\mathrm{PH}$ into 5 groups and PAH is class I with pulmonary artery wedge pressure (PAWP) $\leq 15 \mathrm{mmHg}$ and pulmonary vascular resistance $(\mathrm{PVR})>3.0$ Woods units. It is a rare and severe condition, with no effective therapeutic option, accompanied by pulmonary arteriole vascular remodeling, luminal stenosis, endothelial dysfunction, and in situ thrombosis
[1]. It also causes pulmonary vasculature reconstruction, which leads to right ventricular failure and is the leading cause of death. Epidemiological studies [2] have shown that the 5-year overall survival rate of patients with PAH is only $59 \%$. However, data indicate that many patients with $\mathrm{PAH}$ and right ventricular failure will die within 2 to 3 years after diagnosis if left untreated. Accurate diagnosis and classification are key to the overall survival rate. However, the pathogenic mechanism of PAH has not yet been elucidated.

Over the past 20 years, new drugs have promoted innovation in PAH therapy. Strategies targeting crucial pathways, including the endothelin-1 (ET-1),

*Correspondence should be addressed to: Drs. Zhuang Tian (email: tianzhuangcn@sina.com) and Shu-Yang Zhang (email: shuyangzhang103@nrdrs.org), Peking Union Medical College Hospital, Academy of Medical Sciences, Beijing, China.

Copyright: () 2020 Xiao Y et al. This is an open-access article distributed under the terms of the Creative Commons Attribution License, which permits unrestricted use, distribution, and reproduction in any medium, provided the original author and source are credited. 
prostacyclin, and nitric oxide (NO) pathways, have been established and are widely used in clinical practice. Other adjuvant therapies, including iron supplementation, oxygen inhalation, and anticoagulation, require further evidence to demonstrate their utility in PAH therapy. Multiple prospective cohort studies have found that shortterm prognosis has significantly improved, but mortality is still high, and long-term outcomes are uncertain. The aim is to explore the underlying molecular mechanisms and seek other novel therapeutic targets to improve the quality of existing therapeutic approaches. More recently, the $6^{\text {th }}$ World Symposium On Pulmonary Hypertension (WSPH), held in 2018 in Nice, France, reiterated the classification in 5 distinct groups of pulmonary hypertension based on different pathologies and etiological factors [3]. This review mainly focuses on class I PAH.

\section{Epidemiology and clinical symptoms}

PAH is one of five categories of pulmonary hypertension defined by a mean pulmonary arterial pressure (mPAP) $\geq$ $25 \mathrm{mmHg}$ at rest, a normal capillary wedge pressure $\leq 15$ $\mathrm{mmHg}$, and a pulmonary vascular resistance (PVR) $>3$ Wood units [2]. PAH is associated with many predisposing factors and is a highly heterogeneous condition, with the etiology varying among races and districts. PAH may occur in the absence of known genetic mutations or other comorbidities - referred to as idiopathic PAH (IPAH) - or be caused by mutations, which is referred to as heritable PAH (HPAH). PAH is also associated with connective tissue disease (CTD$\mathrm{PAH}$ [4], HIV infection, and drug and toxin usage (fenfluramine, anorexigens, methamphetamine, etc.). PAH may also be associated with pulmonary venoocclusive disease or capillary hemangiomatosis (PVOD/PCH) and congenital heart disease (CHD-PAH). The prevalence of $\mathrm{PAH}$ is approximately 15-60 per million individuals, with an incidence of 5-10 per million individuals per year [5]. IPAH accounts for 35-67\% of PAH cases, with an estimated incidence of 1.1-7.6 cases per million individuals according to the US and EU national registries [6]. The French Pulmonary Hypertension Registry [7] indicated that 51 patients with systemic lupus erythematosus (SLE)-associated PAH had an overall 5-year survival rate of $83.9 \%$ after diagnosis of the disease. The delay between SLE diagnosis and PAH diagnosis was 4.9 years (range 2.8-12.9 years). The 3 - and 5 -year overall survival rates were $89.4 \%$ (95\% CI, 76.2\%$96.5 \%$ ) and $83.9 \%$ (95\% CI, 68.8\%-92.1\%), respectively. Anti-SSA/SSB antibodies may be a risk factor for PAH, and the presence of anti-U1-RNP antibodies appears to be a protective factor that influences survival.
The common clinical symptoms of pulmonary hypertension mainly include chest tightness, shortness of breath, and decreased tolerance for progressive activities. As the disease progresses, right ventricular hypertrophy and RV fibrosis develop, accompanied by impaired diastolic function and congestion of systemic circulation. Dyspnea, edema and syncope complications influence the progressive decline in right heart function, causing right heart failure (RHF). The early symptoms may not be typical and are often ignored by patients until right ventricle decompensation. Timely identification of RHF and risk stratification are essential for prognosis and avoidance of lung transplantation in end-stage PAH.

The average survival of PAH patients is approximately 2.8 years in the absence of an effective treatment after diagnosis [8]. The US Food and Drug Administration (FDA) has approved 14 drugs for PAH treatment, mainly targeting pulmonary vasculature vasoconstriction. Endothelin receptor antagonists (ERAs), prostacyclin analogues (PCAs), phosphordiesterase 5 inhibitors (PDE-Is), and soluble guanylate cyclase stimulators (sGCs) with diverse drug administration routes have been approved in PAH therapy. The French Pulmonary Hypertension Registry [9] collected $674 \mathrm{PAH}$ patients from 17 French centers from October 2002 to October 2003 and found that the 1year, 2-year, and 3-year survival rates were $87 \%, 76 \%$, and $67 \%$, respectively. Despite the emergence of vasodilator therapies, PAH remains incurable, and mortality rates are still high. Research has focused on identifying novel therapeutic drugs encompassing broader aspects of the pathophysiology of PAH to improve its prognosis.

PAH remains an incurable and costly disease with a high mortality rate. Accurate diagnosis of PAH is critical for targeted therapy [10], which may require the involvement of PAH centers [11]. The therapeutic regime varies depending upon the distinct risk classification. In newly diagnosed patients, initial combination therapy with ambrisentan and tadalafil is recommended over monotherapy to achieve the best therapeutic outcome[12]. Intravenous administration of prostacyclin is the only therapy that reduces PAH mortality. Advances in diagnostic algorithms and guidelines for risk groups are imminent owing to the reduction in screening time from symptom onset to diagnosis, the predominant determining factor in prognosis. Validated integration algorithms will be essential for diagnosing PAH in the near future [13].

\section{Pathological mechanisms}

\subsection{Gene mutations associated with PAH}

PAH is a genetically heterogeneous disease characterized by vascular remodeling primarily affecting the small 
pulmonary arterioles $(<100 \mathrm{~mm})$. Remodeling of the pulmonary vasculature involves the obliteration of pulmonary arterioles, muscularization of peripheral arteries and formation of plexiform lesions, which cause the progressive narrowing of blood vessels. There are more than 10 diseases causing genetic mutations that have been linked to the development of PAH, including bone morphogenetic protein receptor (BMPR2), SMAD family member 9 (SMAD9), activin A receptor-like type 1 (ACVRL1), endoglin (ENG), and eukaryotic translation initiation factor 2 alpha kinase 4 (EIF2AK4).
$B M P R 2$, a member of the TGF- $\beta$ superfamily, belongs to the BMP/TGF signaling pathway that induces osteogenesis and cell differentiation. It is the most important pathogenic gene of PAH. More recently, other rare causal candidate genes have been discovered. Whole exon sequencing (WES) screening demonstrated that $T$ box 4 (TBX4) [14], a gene linked to small patella syndrome 8 , is the most commonly mutated gene in pediatric patients with HPAH along with BMPR2. Table 1 lists the latest variants associated with PAH mutations.

Table 1. Gene variants associated with pulmonary arterial hypertension.

\begin{tabular}{|c|c|c|c|c|c|c|}
\hline Gene & Gene ID & Chromosome & Disease & Function & Name & Refs \\
\hline BMPR2 & 659 & $2 q 33.1-q 33.2$ & $\begin{array}{l}\text { IPAH } \\
\text { HPAH }\end{array}$ & $\begin{array}{l}\text { Member of the TGF- } \beta \\
\text { receptor family }\end{array}$ & $\begin{array}{l}\text { Bone morphogenetic } \\
\text { protein receptor type } 2\end{array}$ & $\begin{array}{l}{[29]} \\
{[19]}\end{array}$ \\
\hline ACVRL1 & 94 & $12 \mathrm{q} 13.13$ & $\begin{array}{l}\mathrm{HHT} / \mathrm{PAH} \\
\text { HPAH }\end{array}$ & $\begin{array}{l}\text { Receptor for the TGF- } \beta \\
\text { superfamily }\end{array}$ & $\begin{array}{l}\text { Activin A receptor-like } \\
\text { type } 1 \text { (ALK1) }\end{array}$ & $\begin{array}{l}{[116]} \\
{[117]}\end{array}$ \\
\hline$E N G$ & 2022 & $9 q 34.11$ & HHT/PAH & $\begin{array}{l}\text { Coreceptor of the TGF- } \beta \\
\text { family }\end{array}$ & Endoglin & [118] \\
\hline SMAD9 & 4093 & $13 q 13.3$ & HPAH & $\begin{array}{l}\text { Transduces signals from } \\
\text { the TGF- } \beta \text { family }\end{array}$ & SMAD family member 9 & [119] \\
\hline KCNK3 & 3777 & $2 \mathrm{p} 23.3$ & $\begin{array}{l}\text { HPAH } \\
\text { IPAH }\end{array}$ & $\begin{array}{l}\text { Encodes the TASK-1 } \\
\text { channel, contributes to } \\
\text { the membrane potential }\end{array}$ & $\begin{array}{l}\text { Potassium two-pore } \\
\text { domain channel } \\
\text { subfamily K member } 3\end{array}$ & [120] \\
\hline EIF $2 A K 4$ & 440275 & $15 q 15.1$ & PVOD/PCH & $\begin{array}{l}\text { Phosphorylates } \\
\text { eukaryotic translation } \\
\text { initiation factor-2 (EIF2) }\end{array}$ & $\begin{array}{l}\text { Eukaryotic translation } \\
\text { initiation factor } 2 \text { alpha } \\
\text { kinase } 4\end{array}$ & [121] \\
\hline$T B X 4$ & 9496 & $17 \mathrm{q} 23.2$ & $\begin{array}{l}\text { Small patella } \\
\text { syndrome, } \\
\text { PAH in children }\end{array}$ & $\begin{array}{l}\text { Involved in the } \\
\text { development of lung } \\
\text { disease }\end{array}$ & T-box 4 & $\begin{array}{c}{[14]} \\
{[122]}\end{array}$ \\
\hline BMP9 & 2658 & $10 q 11.22$ & $\begin{array}{l}\text { HPAH } \\
\text { IPAH }\end{array}$ & $\begin{array}{l}\text { Binds the TGF- } \beta \\
\text { receptor }\end{array}$ & $\begin{array}{l}\text { Bone morphogenetic } \\
\text { protein } 9 \text { or growth } \\
\text { differentiation factor } 2\end{array}$ & {$[15]$} \\
\hline
\end{tabular}

IPAH: idiopathic pulmonary arterial hypertension, HPAH: heritable pulmonary arterial hypertension, HHT: hereditary hemorrhagic telangiectasia, PVOD/PCH: pulmonary veno-occlusive disease and/or pulmonary capillary hemangiomatosis.

Recent reports suggest that mutations in BMP9 may be a newly identified cause of PAH. BMP9, also known as growth and differentiation factor 2 , is predominantly expressed in the liver and is constitutively secreted into the bloodstream. By binding to ACVRL1 (type I BMP receptor) and BMPR2, BMP9 plays an important role in regulating vascular function and angiogenesis. Gräf et al. found BMP9 gene mutations in IPAH/HPAH patients among a European Caucasian population through GWES screening. Moreover, Jing et al. [15] identified a new pathogenic gene for PAH. It was found in $6.7 \%$ of IPAH cases in the Chinese population, where the incidence of IPAH has increased 22-fold. Using recombinant $B M P 9$ could alleviate hemodynamics in a BMPR2-deficient PAH mouse model [16]. Emerging evidence suggests that $B M P 9$ functions to improve cardiac fibrosis in heart failure [17]; BMP9-knockout mice exhibited normal cardiac development. However, one study found that a $B M P 9^{(--)}$transgenic model and a $B M P 9$ inhibitor reduced right ventricular hypertrophy and distal muscularization of pulmonary arteries and reversed the hemodynamic parameters of hypoxic-PH mice [18]. Meanwhile, a neutralizing anti-BMP9 antibody reduced the proliferation of pulmonary vascular cells and inflammatory cell infiltration in PH mice and protected the PH group. The above results require careful analysis.

3.1.1 BMPR 2 mutations and the TGF- $\beta$ signaling pathway

$B M P R 2$ mutations increase the susceptibility to PAH. The BMPR2 protein mainly consists of 3 structures, including the ligand-binding domain, the serine-threonine kinase domain, and the cytoplasmic tail. A meta-analysis of 1,550 PAH patients [19] found that those with BMPR2 mutations were younger and had a more severe form of $\mathrm{PAH}$, associated with high mortality and poor prognosis, than those with normal BMPR2. BMPR2 haploinsufficiency is associated with increased endothelial apoptosis, transformational EC metabolism, and PASMC 
proliferation, which facilitate the development of pulmonary hypertension. BMPs, especially BMP-6 [20], could regulate the proliferation of lymphocytes such as $B$ cells, $\mathrm{T}$ cells, and macrophages through BMPR2. Downregulation of BMPR2 signaling deleteriously affects granulocyte macrophage colony-stimulating factor (GM-CSF) translation and immune cell recruitment to aggravate PH [21]. In addition, BMPR2 loss of function enhances inflammation in fibroblasts [22].

Van der Bruggen et al. [23] demonstrated that individuals with PAH and BMPR2 mutations have worse right ventricular function than those with $\mathrm{PAH}$ and normal $B M P R 2$. In addition, animal studies found that [24] BMPR2-mutant mice showed decreased exercise capacity and poor response to stress load and that myocardial hypertrophy in animals was accompanied by right ventricular energy metabolism disorder.

How does BMPR2 affect the pathogenesis and disease progression of PAH? Familial PAH (FPAH) is considered to be an autosomal dominant disease, and 70\% of patients afflicted with the disease exhibit BMPR2 germline mutations [25]. Twenty-five percent of IPAH cases are associated with BMPR2 gene mutations. Among patients with a family history of $\mathrm{PAH}, 58-74 \%$ have BMPR2 mutations, which are present in $3.5-40 \%$ of patients with IPAH [26].

Almost $80 \%$ of BMPR2 mutation carriers do not necessarily progress to PAH [27], highlighting their incomplete penetrance. With this background, there are significant sex differences. The penetrance rate of $B M P R 2$ mutations in women is $42 \%$, compared with $14 \%$ in men [28]. Therefore, the hereditary, environmental and epigenetic regulatory mechanisms that cause BMPR2 dysfunction are implicated in disease pathogenesis. There are more than 144 distinct $B M P R 2$ mutations that inhibit protein function found in PAH patients [29]. The possible mechanisms of BMPR2 degradation include the lysosomal degradation pathway and the TNF- $\alpha$-mediated ubiquitination process. Drugs that increase BMPR2 expression and degradation have been exploited for preclinical trials [30].

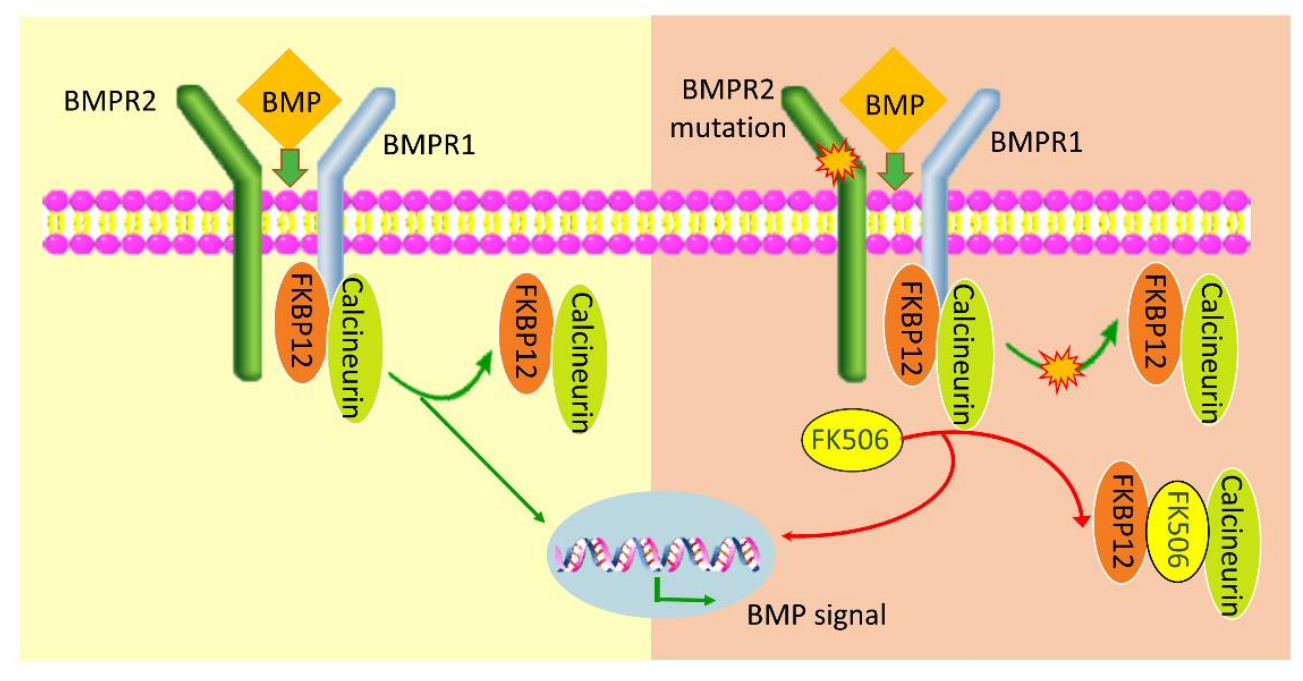

Figure 1. Activation of BMP signaling with or without mutated BMPR2 and the pharmacological mechanism of FK506. BMP signaling in the presence of normal or mutated dysfunctional BMPR 2 . Mutated BMPR2 protein disturbs the dissociation of FKBP12-calcineurin from BMPR1 when stimulated by activating doses of BMPs. FK506 binds to FKBP12 and promotes the dissociation of FKBP12calcineurin from BMPR type 1 receptors and then activates the downstream signaling pathway. BMP: bone morphogenetic protein; FKBP12: FK506-binding protein 12.

\subsubsection{FK506}

FK506 (tacrolimus), a calcineurin inhibitor and a BMPR2 activator, is the binding partner of FKBP12, which is a 12$\mathrm{kDa}$ FK506-binding protein and pharmacological target of FK506. Spiekerkoetter et al. [31] reported that a low dose of FK506 (tacrolimus, $15 \mathrm{ng} / \mathrm{ml}$ ) could reverse occlusive vasculopathy in MCT and sugen-hypoxiainduced PAH rat models and inhibit the suppression of the
BMPR2 signaling pathway. FK506 is an immunesuppressant widely used as an ointment in the treatment of atopic dermatitis.

The $B M P R 2$ mutation impairs the function and prevents the dissociation of FKBP12-calcineurin from BMPR type 1 receptors (ALK1, ALK2, and ALK3) when exposed to the subactivating ligand of BMPs. FK506 binds to FKBP12, causing its detachment from the BMPR type 1 receptors, thus activating BMPR2-mediated 
signaling. Interestingly, a previous study [32] also showed that high doses of FK506 (>10-fold higher than the dose of the above study) induced systemic hypertension and nephrotoxicity by enhancing ET-1 production and inhibiting endothelial nitric oxide synthase (eNOS) activity in mouse models. Fig. 1 depicts the activation of the BMP signal with or without mutated $B M P R 2$ and the pharmacological mechanism of FK506.

Table 2. Clinical trials and potential therapeutic targets in pulmonary arterial hypertension.

\begin{tabular}{|c|c|c|c|c|c|c|c|}
\hline Drug/agent & Mechanism & $\begin{array}{l}\text { ClinicalTrials.gov } \\
\text { identifier }\end{array}$ & Participants & Study design & $\begin{array}{l}\text { Study } \\
\text { duration }\end{array}$ & $\begin{array}{l}\text { Primary outcome } \\
\text { measure }\end{array}$ & Outcome \\
\hline $\begin{array}{l}\text { Tacrolimus } \\
\text { (FK506) }\end{array}$ & $\begin{array}{l}\text { Activator of BMP } \\
\text { signaling }\end{array}$ & NCT01647945 & $\begin{array}{l}23 \text { patients } \\
\text { with PAH }\end{array}$ & $\begin{array}{l}\text { Single center, phase II } \\
\text { randomized, placebo- } \\
\text { controlled study }\end{array}$ & $\begin{array}{l}16 \\
\text { weeks }\end{array}$ & $\begin{array}{l}\text { Safety of low-dose } \\
\text { FK-506 in PAH }\end{array}$ & Completed \\
\hline Tocilizumab & $\begin{array}{l}\text { Humanized anti- } \\
\text { IL6R antibody }\end{array}$ & NCT02676947 & $\begin{array}{l}29 \text { patients } \\
\text { with group } 1 \\
\text { PAH }\end{array}$ & $\begin{array}{l}\text { Open-label phase II } \\
\text { trial }\end{array}$ & 6 months & $\begin{array}{l}\text { Safety in terms of the } \\
\text { incidence and severity } \\
\text { of adverse events }\end{array}$ & Completed \\
\hline Anakinra & $\begin{array}{l}\text { Recombinant IL-1 } \\
\text { receptor } \\
\text { antagonist }\end{array}$ & NCT03057028 & $\begin{array}{l}6 \text { patients with } \\
\text { stable PAH and } \\
\text { RV failure }\end{array}$ & $\begin{array}{l}\text { Single-arm, open- } \\
\text { label, phase IB/II pilot } \\
\text { study }\end{array}$ & 14 days & $\begin{array}{l}\text { Change in exercise } \\
\text { capacity as determined } \\
\text { by peak oxygen } \\
\text { consumption and } \\
\text { ventilatory efficiency }\end{array}$ & Completed \\
\hline Rituximab & $\begin{array}{l}\text { Anti-CD20 } \\
\text { antibody }\end{array}$ & NCT01086540 & SSc-PAH & $\begin{array}{l}\text { Double-blind, } \\
\text { placebo-controlled, } \\
\text { phase II, multicenter, } \\
\text { randomized trial }\end{array}$ & $\begin{array}{l}48 \\
\text { weeks }\end{array}$ & $\begin{array}{l}\text { Change from baseline } \\
\text { in } 6 \mathrm{MWD}\end{array}$ & $\begin{array}{l}\text { Active, not } \\
\text { recruiting }\end{array}$ \\
\hline $\begin{array}{l}\text { Dichloroacetic } \\
\text { acid } \\
\text { (DCA) }\end{array}$ & $\begin{array}{l}\text { Inhibition of } \\
\text { pyruvate } \\
\text { dehydrogenase } \\
\text { kinase }\end{array}$ & NCT01083524 & $\begin{array}{l}20 \text { adult } \\
\text { patients with } \\
\text { IPAH }\end{array}$ & $\begin{array}{l}\text { Phase I, open-label, } \\
\text { two-center study }\end{array}$ & $\begin{array}{l}28 \\
\text { weeks }\end{array}$ & $\begin{array}{l}\text { Safety and tolerability } \\
\text { of DCA }\end{array}$ & Completed \\
\hline $\begin{array}{l}\text { Apabetalone } \\
\text { (RVX-208) }\end{array}$ & BET inhibitor & NCT03655704 & $\begin{array}{l}\text { Estimated } 10 \\
\text { participants }\end{array}$ & $\begin{array}{l}\text { Early phase I, two- } \\
\text { center, open-label trial }\end{array}$ & $\begin{array}{l}16 \\
\text { weeks }\end{array}$ & Change in PVR & Recruiting \\
\hline Olaparib & PARP1 inhibitor & NCT03251872 & $\begin{array}{l}\text { Estimated } 6 \\
\text { participants }\end{array}$ & $\begin{array}{l}\text { Open-label, early } \\
\text { phase I trial }\end{array}$ & $\begin{array}{l}16 \\
\text { weeks }\end{array}$ & Change in PVR & Recruiting \\
\hline Anastrozole & Estrogen inhibitor & NCT01545336 & 18 participants & $\begin{array}{l}\text { Double-blind, } \\
\text { placebo-controlled, } \\
\text { phase II study }\end{array}$ & 3 months & $\begin{array}{l}\text { Plasma estradiol (E2) } \\
\text { level, tricuspid annular } \\
\text { plane systolic } \\
\text { excursion (TAPSE) }\end{array}$ & Completed \\
\hline Metformin & $\begin{array}{l}\text { Multifunctional } \\
\text { aromatase } \\
\text { inhibitor and } \\
\text { AMPK activator }\end{array}$ & NCT03617458 & $\begin{array}{l}160 \\
\text { participants }\end{array}$ & $\begin{array}{l}\text { Phase II, } 2 \times 2 \\
\text { factorial, randomized, } \\
\text { blinded trial }\end{array}$ & $\begin{array}{l}12 \\
\text { weeks }\end{array}$ & $\begin{array}{l}\text { Change from baseline } \\
\text { in } 6 \mathrm{MWD}\end{array}$ & Recruiting \\
\hline Imatinib & $\begin{array}{l}\text { Selective tyrosine } \\
\text { kinase inhibitor }\end{array}$ & NCT01392495 & 17 participants & $\begin{array}{l}\text { Open-label, phase III, } \\
\text { nonrandomized trial }\end{array}$ & $\begin{array}{l}144 \\
\text { weeks }\end{array}$ & $\begin{array}{l}\text { Number of patients } \\
\text { with adverse event and } \\
\text { deaths }\end{array}$ & $\begin{array}{l}\text { Terminated for } \\
\text { severe adverse } \\
\text { effects }\end{array}$ \\
\hline $\begin{array}{l}\text { Bardoxolone } \\
\text { methyl }\end{array}$ & $\begin{array}{l}\text { Nrf2 pathway- } \\
\text { activating agent }\end{array}$ & NCT02657356 & $\begin{array}{l}202 \\
\text { participants } \\
\text { with CTD- } \\
\text { PAH }\end{array}$ & $\begin{array}{l}\text { Phase III, double- } \\
\text { blind, randomized, } \\
\text { placebo-controlled } \\
\text { trial }\end{array}$ & $\begin{array}{l}24 \\
\text { weeks }\end{array}$ & $\begin{array}{l}\text { Change from baseline } \\
\text { in } 6 \mathrm{MWD}\end{array}$ & Not recruiting \\
\hline $\begin{array}{l}\text { Gene-enhanced } \\
\text { EPCs } \\
\text { (PHACeT trial) }\end{array}$ & Cell therapy & NCT00469027 & $\begin{array}{l}7 \text { participants } \\
\text { with PAH }\end{array}$ & $\begin{array}{l}\text { Phase I, open-label, } \\
\text { dose-escalation study }\end{array}$ & 5 years & $\begin{array}{l}\text { Tolerability and safety } \\
\text { of the injection of } \\
\text { genetically engineered } \\
\text { progenitor cells }\end{array}$ & Completed \\
\hline $\begin{array}{l}\text { Pulmonary } \\
\text { artery } \\
\text { denervation } \\
\text { (PADN) }\end{array}$ & $\begin{array}{l}\text { Inhibitor of } \\
\text { sympathetic } \\
\text { stimulation }\end{array}$ & NCT02284737 & $\begin{array}{l}\text { Estimated } 270 \\
\text { participants }\end{array}$ & $\begin{array}{l}\text { Phase IV, prospective, } \\
\text { multicenter, } \\
\text { randomized control } \\
\text { trial }\end{array}$ & 6 months & $\begin{array}{l}\text { PAH-related events, } \\
\text { death including lung } \\
\text { transplantation, atrial } \\
\text { septostomy, worsening } \\
\text { of PAH }\end{array}$ & Recruiting \\
\hline
\end{tabular}

DCA: dichloroacetic acid; DMF: dimethyl fumarate; Nrf2: nuclear factor erythroid 2-related factor 2; PADN: pulmonary artery denervation; PAH: pulmonary arterial hypertension; 6MWD: six-minute walk distance; SSc-PAH: systemic sclerosis with pulmonary arterial hypertension; EPCs: endothelial progenitor cells; IPAH: idiopathic pulmonary arterial hypertension; CTD-PAH: pulmonary arterial hypertension associated with connective tissue disease.

Furthermore, a single center, 16-week, phase IIa RCT ensured the safety and tolerability of FK506. It revealed that [33] a low dose of FK506 could improve endothelial dysfunction and reverse pulmonary hypertension in stable PAH patients with great tolerance.
However, the improvements in six-minute walk distance (6MWD) and heart failure were not significant when compared to adverse effects such as nausea and diarrhea (NCT01647945, Table 2). The results related to FK506 shed some light on drug therapies based on the 
pathogenesis of PAH. Toxicity should also be accounted for before starting clinical studies.

\subsection{Apoptosis of PAECs and proliferation of PASMCs}

PAH is characterized by apoptosis resistance phenotypes of pulmonary arterial endothelial cells (PAECs) and enhanced proliferation of pulmonary arterial smooth muscle cells (PASMCs) from the perspective of pathological insights, which drive the progression of $\mathrm{PAH}$. However, the underlying mechanisms remain unclear, and a novel treatment option is desperately needed to combat the progression of disease. PAH-SMCs featured increased production of inflammatory factors and adaptation of mitochondrial metabolism to a hyperproliferative state, similar to cancer cells, suggesting that PAH-SMCs are different from SMCs isolated from healthy individuals. Vascular remodeling and muscularization of distal pulmonary arterioles resulted in right ventricular failure, causing death. Finding novel treatments that reverse pulmonary vascular remodeling remains an urgent need.

Drugs that target PASMC proliferation may shed new light on novel treatment strategies. Investigation into the molecular mechanisms of PASMCs revealed the pharmaceutical effects of celastramycin in PAH [34] via high-throughput screening. Celastramycin, a benzoyl pyrrole-type compound, ameliorates pulmonary hypertension in three experimental PAH animal models by reducing excessive proliferation of PASMCs, leading to less inflammation and cytosolic reactive oxygen species (ROS) levels, as well as recovering mitochondrial energy metabolism. It may be a promising potential drug for PAH.

Evidence has shown that in vivo pharmacological activation of KCNK3 channels has beneficial effects in monocrotaline-induced $\mathrm{PH}$ in rats. Furthermore, inhibition of voltage-gated potassium channels could represent one potential mechanism involved in some drug-induced $\mathrm{PH}$.

In addition, PAECs have been strongly implicated in PAH pathogenesis because the existing drugs mainly target endothelium vasodilatation-associated pathways. Recent preclinical studies with PASMC/PAEC-specific target gene knockout mice are the ideal tool for research on vascular endothelial injury at the cellular or animal level.

\subsection{Inflammation in PAH}

The inflammatory signaling pathway may also be a key factor in the pathologic progression of $\mathrm{PAH}$, particularly in terms of associated PAH. Although we have recognized this phenomenon for many decades, the understanding of inflammatory molecules in PAH is still limited. Epidemiological studies [35, 36] and an experimental research study [37] have found that PAH is associated with immune dysregulation and abnormal B cell, NK lymphocyte, and regulatory $\mathrm{T}$ cell (Treg) activity. Innate immune system dysfunction is associated with plexiform lesions of PAH. This finding suggests that inflammation and autoimmune mechanisms are closely related to the prognosis and survival of PAH patients.

Histopathology studies of PAH patient lungs support the hypothesis of inflammation as a powerful pathological driver of PAH. PAH patients generally exhibit signs of chronic inflammation even without an immune-related condition, most prominently delineated by elevated circulating cytokine levels and perivascular inflammatory infiltrates [38, 39]. In addition, PAH can present autoimmune features such as elevated anti-nuclear, antifibroblast, and anti-endothelial cell antibodies. The pathological process is accompanied by the accumulation of perivascular inflammatory cells, such as macrophages, dendritic cells, mast cells and $\mathrm{T}$ and $\mathrm{B}$ lymphocytes, which are mainly distributed in the submucosa around remodeling pulmonary vessels. Furthermore, dysfunction of BMPR2 in fibroblasts can cause elevated inflammation. Because the present treatments are not curative, the clinical management of patients primarily focuses on achieving a symptom-free condition, aiming to improve quality of life.

Inflammatory cells aggregate around the vascular walls and elevate peripheral blood inflammatory cells simultaneously. The levels of various pro-inflammatory cytokines in the blood are associated with the survival rate of patients. Moreover, some research has discovered impairment of cellular immunity (T lymphocytes, natural killer (NK) cells, and macrophages) in patients with PAH [40-42]. NK cells are being identified as important regulators of vascular remodeling in different physiological and pathological conditions. NK cells isolated from $\mathrm{PAH}$ patients exhibit an impaired phenotype with high responsiveness to transforming growth factor- $\beta$ (TGF- $\beta$ ), accompanied by reduced disease-associated killer immunoglobulin-like receptors and matrix metalloproteinase 9 production [41]. Additionally, CD4+ CD25+ Foxp3+ regulatory T-cells (Tregs), identified as a key type of potent immunomodulator of the adaptive immune system, have also been reported to be important in PAH [43]. Athymic nude rats lacking Tregs showed exaggerated lung vascular injury, macrophage recruitment, and elevated pulmonary pressure induced by vascular endothelial growth factor receptor 2 (VEGFR2) blockade [44]. Many retrospective and prospective analyses have found that patients with PAH have elevated levels of the cytokines interleukin-1 $\beta$, IL-6, and IL- 8 and the chemokine CCL2/MCP-1, among others [45, 46]. 
Moreover, the increased circulating concentrations of certain pleiotropic cytokines and inflammatory substances cause a regulatory immune response through canonical and noncanonical signal transduction pathways.

It has been shown that inflammation may play a significant role in the prognosis and treatment response in CTD-PAH. Patients with a simultaneous diagnosis of PAH and a CTD, including SLE (systemic lupus erythematosus), MCTD (mixed connective tissue disease), and primary SS (Sjögren's syndrome), tend to benefit from receiving first-line intensive immunosuppressive regimens, which are accompanied by better cumulative rates free of PAH-related death as well as better short-term and long-term outcomes [47]. Sun et al. [48] demonstrated two distinct inflammatory phenotype clusters of SLE-PAH, the vasculopathic and vasculitic subtypes. The vasculitic subtype shows systemic manifestations, high SLE disease activity, and a highly inflammatory phenotype. A score was calculated by combining the time interval between the diagnosis of SLE and PAH and the Systemic Lupus Erythematosus Disease Activity Index (SLEDAI) score and based on the clinical phenotypes associated with the weighted score. The vasculitic subtype had the desirable 3-year treatment goal achievement (TGA) rate of $71.2 \%$, compared with the $60.7 \%$ TGA rate in the vasculopathic subtype $(\mathrm{p}=$ 0.31 HR $1.34,95 \%$ CI 0.76 to 2.31 ). The mortality and prognosis were not worse than those of the vasculopathic subtype [49]. This evidence indicates that PAH patients with a stronger inflammatory profile may have a better treatment response to immunosuppressant therapy than those with a weaker inflammatory profile. However, no definitive conclusion can be made before clinical trials to eliminate the influence of comorbidities, heterogeneity of disease, and other confounding factors. Treatment protocols for SLE-PAH should be scrutinized on account of the high mortality associated with this disease.

It remains unknown whether inflammation is the cause of pulmonary vascular remodeling or is nothing but the consequence of the pulmonary high-pressure microenvironment. Novel drugs with anti-inflammatory or immunomodulatory properties may be potent therapeutic targets but are still obscure given that many patients fail to respond to broad immunosuppressive therapy with corticosteroids. The following is a list of the different biological effects and possible mechanisms targeting different inflammatory factors and immune profiles in $\mathrm{PAH}$.

\subsubsection{IL-6}

IL-6 is a multifunctional pro-inflammatory cytokine that is elevated in the serum of patients with $\mathrm{PAH}$ and can be used to predict the survival rate of IPAH. Hypoxic signaling likely contributes to the inflammatory milieu of $\mathrm{PH}$ as well. IL-6 plays an important role in immune regulation as well as metabolic, proliferative, and regenerative processes in the body. A study [50] showed that transgenic mice with lung tissue-specific IL-6 overexpression featured spontaneous $\mathrm{PH}$ and pulmonary vascular occlusion at normal oxygen partial pressure, whereas hypoxia aggravated the severity of PH. In addition, mice with specific knockout of IL-6R exhibit resistance to hypoxia-induced pulmonary hypertension $(\mathrm{HPH})$. Further animal experiments revealed that IL-6 continuously activated the inflammatory response by activating the FGF pathway, stimulating apoptosis of ECs and PASMC proliferation, and disrupting the BMPR2 signaling pathway.

Clinical studies have reported [51, 52] that high levels of inflammatory mediators are predictive of survival rate and that the severity of right ventricular failure is associated with worse outcomes. Animal studies provide further evidence regarding the usefulness of immunotherapy in PAH. Experiments have confirmed that [53] a recombinant IL-6 receptor antagonist can reverse pulmonary artery remodeling in experimental PAH models and protect heart function. Patients with IPAH and HPAH had increased IL-6 levels in serum and lung dissection samples along with autoimmune disorders, which are associated with an increased risk of death. PAH-PASMCs showed upregulated expression of IL-6R, with IL-6 appearing to signal both via the membrane-bound (classic or cis) pathway and the transsignaling pathway (gp130). Tocilizumab, a humanized anti-IL6R monoclonal antibody approved for rheumatoid arthritis, disturbs both classical and trans-signaling and improved the symptoms in a patient with mixed connective tissue disease and severe refractory PAH [54]. An open-label phase II trial was performed to evaluate the safety and efficacy of tocilizumab in 29 patients with class I PAH (ClinicalTrials.gov identifier: NCT02676947). Inhibiting all IL-6 signaling might exert severe adverse effects because IL-6 plays a vital role in the physiological functioning of the body. Evidence suggests that [55] patients with weakened adaptive immunity respond positively and benefit more from IL-6 antagonist therapy than patients with normal adaptive immunity. Thus, it is important to identify the patients who would benefit most from IL6R-inhibiting treatment [56].

\subsubsection{IL-1}

The interleukin-1 (IL-1) family comprises three ligands: IL-1 $\alpha$, IL-1 $\beta$, and IL-1 receptor antagonist (IL-1Ra). Elevated levels of IL-1 have been implicated in human PAH diseases [52, 57]. IL-1 receptor antagonist (IL-1Ra) was shown to prevent the development of pulmonary 
hypertension in monocrotaline-induced rats more than two decades ago, although this has never been investigated in humans with PAH. Anakinra, an IL-1Ra, is currently U.S. FDA-approved for use in rheumatoid arthritis, Castleman's disease, and juvenile arthritis but has also demonstrated efficacy in a wide array of inflammatory conditions. An expanding role for IL-1 is emerging with the development of biomedicine.

IL- $1 \alpha$ and IL- $1 \beta$ are synthesized by monocytes, macrophages, neutrophils, hepatocytes, and other cells in vivo, and their precursor molecules become biologically active when cleaved by the enzyme caspase-1. There are two distinct forms of IL-1R, the activated IL-1RI containing the long cytoplasmic domain and the biologically inert IL-1RII containing a short intracellular domain. IL-1R accessory protein (IL-1RAcP), another IL1 family member, could interact with the IL-1/IL-1RI combination to form a macromolecular complex by recruiting MyD88 (myeloid differentiation factor 88), IRAK (IL-1R-associated kinase), and TRAF6 (tumor necrosis factor (TNF) receptor-associated factor 6) to activate signal transduction pathways such as the nuclear factor- $\kappa \mathrm{B}(\mathrm{NF}-\kappa \mathrm{B}), \mathrm{AP}-1$ (activator protein-1), JNK (cJun N-terminal kinase), and p38 MAPK (mitogenassociated protein kinase) pathways.

The ambiguous function of IL-1 in PAH is attracting increasing interest from both bioscience and medical research alike. Parpaleix et al. [58] revealed that IL-1R1(/-), MyD88(-/-), and control mice given the IL-1R1 antagonist anakinra are protected against hypoxic pulmonary hypertension and perivascular macrophage recruitment. Interleukin (IL)- $1 \beta$ binds to IL-1R 1 , thereby recruiting the molecular adaptor MyD88 and inducing IL1 , IL- 6 and TNF- $\alpha$ synthesis through NF- $\kappa$ B activation.

Recently, Trankle and colleagues [59] reported the effects of anakinra in PAH in their pilot study. The singlearm, open-label, phase IB/II pilot study found that IL-1 blockade could reduce inflammation in $\mathrm{PAH}$ and reverse right venticular failure (RVF). These results call for further exploration of anakinra to address the systemic inflammatory component of PAH. Anakinra reversed pulmonary hypertension partially through IL-1 receptor 1/MyD88 signaling and markedly attenuated pulmonary vessel remodeling in monocrotaline-treated rats. This study evaluated the safety and feasibility of anakinra in the treatment of stable PAH patients with complicated RHF based on standard drug therapy. It was found that anakinra reduced the inflammatory load by reducing serum hs-CRP levels but without significant clinical benefits owing to the limitations of the study. This study provides clear proof of principle as well as safety and feasibility data supporting IL-1 receptor antagonism with anakinra to address the systemic inflammatory conditions of PAH. Conversely, anakinra is emerging as a potent clinical target in the REDHART study [60] (mainly including patients with acute exacerbation of systolic heart failure).

\subsubsection{CD-20}

Rituximab, an anti-CD20 chimeric monoclonal antibody that targets the B lymphocyte CD20 protein, has been reported to be effective in CTD-PAH and SLE-PAH in case reports [61]. The ongoing phase II randomized clinical trial ASC01 is examining rituximab treatment in SSc-PAH patients (ClinicalTrials.gov identifier: NCT01086540), with a completion date estimated in December 2019. This study mainly focused on 6MWD change at week 24, change in PVR and time to clinical worsening from baseline through week 48. Another animal study [62] also found that targeting IL-17 attenuated hypoxia-induced pulmonary hypertension through downregulation of the $\beta$-catenin pathway.

\subsubsection{TNF- $\alpha$}

Endogenous TNF- $\alpha$ is secreted by activated human $\mathrm{CD}^{+}$ $\mathrm{T}$ cells, causing mitochondrial hyperpolarization, which decreases the $\mathrm{K}^{+}$current, increases the $\mathrm{Ca}^{2+}$ current and activates NFAT in normal human PASMCs. TNF- $\alpha$ inhibits PASMC PDH activity in vivo. A TNF- $\alpha$ antagonist, etanercept [63], prevents and ameliorates symptoms in MCT-induced rodents by decreasing endogenous prostaglandins, improves apoptotic resistance of PASMCs, and activates angiogenesis and adrenergic signaling. However, no significant improvement in heart function or 6MWD was observed.

\subsection{Epigenetic modifications}

Epigenetics refers to phenotype changes mediated by altered gene expression, not DNA sequence [64]. Epigenetic mechanisms can be acquired and/or heritable, and there are three major mechanisms: (i) methylation of $\mathrm{CpG}$ islands mediated by DNA methyltransferases; (ii) histone modification; and (iii) regulation by microRNAs (miRNAs) [65]. Epigenetic perspectives shed new light on how the environment influences gene expression and disease susceptibility in cardiovascular disease. Histone deacetylase (HDAC) dynamically regulates epigenetic programming and is critical for cell proliferation and survival. HDAC inhibitors have been reported to produce opposite effects in different preclinical PAH models [66, 67]. However, little is known about the epigenetic mechanism in PAH. The reversible nature of these epigenetic modifications and the existence of chromatinmodifying enzymes suggest the possibility of epigeneticbased PAH therapy. 
BRD4 is a member of the bromodomain and extraterminal (BET) motif family, members of which are critical epigenetic drivers for many cardiovascular diseases. BRD4 can promote cell survival, stimulate proliferation, inhibit apoptosis, and modulate the proinflammatory phenotype by increasing the transcriptional expression of the cytokines IL-6 and IL-8. It exerts a critical transcriptional modulator function in the context of accumulating DNA damage.

Studies have shown [68] that the overexpression of BRD4 in PAH is closely associated with the aberrant DNA damage response (DDR) mediated by FoxM1. Recently, a preclinical study indicated that [69] inhibiting BRD 4 by using JQ1 and siRNA could enhance pulmonary hemodynamics and alleviate vascular remodeling in sugen5416-hypoxia rats by reducing the apoptosis resistance and proliferation capacity of PAH-SMCs. A new clinical trial with the BRD4 inhibitor apabetalone (RVX-208) in PAH patients is upcoming. The trial number is NCT03655704.

\subsection{DNA damage and repair}

DNA damage may occur when the body encounters endogenous or exogenous genotoxic agents, which results in the impairment of cellular DNA integrity and function. $\mathrm{PAH}$ is associated with inflammation and oxidative stress, which could induce DNA damage. DNA damage and repair dysregulation has been known as a strong trigger for $\mathrm{PAH}$ progression since the discovery of microsatellite instability and somatic genetic mutations in the PAH lung [70, 71].

A study [72] found $30.2 \%$ of PAH-PAECs had chromosomal abnormalities in comparison to $5.3 \%$ of the corresponding control cells. Aside from PAECs, peripheral blood mononuclear cells (PBMCs) obtained from patients or their relatives with $\mathrm{PAH}$ presented an elevated baseline mutation rate and led to mutageninduced DNA damage. A study has also found that poly (ADP-ribose) polymerase-1 (PARP-1), a critical enzyme implicated in DNA repair, was overexpressed in human PAH distal pulmonary arteries and cultured PAHPASMCs [73]. A further animal study showed that the PARP inhibitor veliparib (ABT-888) reduces RV pressure and reverses PAH development as well as RV hypertrophy in sugen-hypoxia- and monocrotalineinduced rat models.

The DNA damage/PARP-1 signaling pathway has the potential to be the next novel therapeutic target for PAH treatment. Another PARP1 inhibitor, olaparib, is in an early phase I clinical trial for PAH (ClinicalTrials.gov identifier: NCT03251872). It is known to inhibit cancer growth and is a safe and effective therapy approved for ovarian cancer in Canada, Europe and the United States.
However, whether DNA damage contributes to lung vascular remodeling and predates $\mathrm{PAH}$ development remains unknown. Targeting DNA damage or PARP signaling is a novel and promising approach to the development of novel therapies for PAH.

\subsection{Estrogen signaling}

The chemical reaction that converts androgens to estrogen is facilitated by aromatase. Aromatase is hyperactive in the pulmonary vasculature of $\mathrm{PAH}$ patients. An epidemiological study has suggested that [74] 70-80\% of patients with $\mathrm{PAH}$ are female. However, many studies have demonstrated [75, 76] the so-called "estrogen paradox": in rodents, the estrogen hormone is protective against $\mathrm{PAH}$ because of pathological mechanisms that are different from those in humans.

Conversely, male PAH patients exhibit a poorer lung transplant-free survival rate and lower overall survival than female patients [77]. Other studies [78, 79] suggested that high levels of estradiol (E2) and low levels of dehydroepiandrosterone sulfate (DHEA-S) were correlated with poor hemodynamics and thus poor outcome of PAH in postmenopausal women and male PAH patients. The MESA study [80] (Multi-Ethnic Study of Atherosclerosis) demonstrated that men had greater RV mass $(\approx 8 \%)$ and larger $\mathrm{RV}$ volumes but lower $\mathrm{RV}$ ejection fraction ( $4 \%$ in absolute terms) than women. The ability of adaptive remodeling of the right ventricle (RV) may explain the roll of sex in PAH survival, as males have a poorer RVEF response when subjected to an increased afterload than females.

Moreover, a study [81] demonstrated that estrogen downregulates the expression of BMPR2. Estrogendriven suppression of BMPR2 signaling may make women prone to $\mathrm{PAH}$ by contributing to a proproliferative phenotype in PASMCs. Recently, a new study [82] found that obesity, which alters estrogen metabolism, could induce $\mathrm{PAH}$ by increasing the production of $16 \alpha$-hydroxyketone (16 $\alpha \mathrm{OHE} 1)$ from visceral adipose tissue, which contributed to oxidative stress. The estrogen inhibitor anastrozole attenuates pulmonary vascular remodeling and increases reactive oxygen species production in the lung in a spontaneous PAH leptin-deficient (ob/ob) mouse model. A small-scale clinical trial tested the estrogen inhibitor anastrozole and found it to be a safe, well-tolerated treatment option for PAH (NCT01545336) [83].

Unfortunately, the functional limitations and reasons for the imbalanced female-to-male ratio in disease prevalence remain unclear. Sex-based differences in sex hormone signaling and its potential beneficial effects are therefore left for future work. 


\subsection{Metabolism dysfunction}

PDK inhibits pyruvate from entering the mitochondria and increases lactate dehydrogenase. Dichloroacetic acid (DCA), a PDK inhibitor, partially restores RV structure and function by promoting glucose and mitochondrial oxidation and reducing pyruvate dehydrogenase phosphorylation in PAH rodent models. A 4-month clinical trial has shown [84] that inhibition of PDK (pyruvate dehydrogenase kinase) improves pulmonary hypertension in genetically susceptible patients. The study revealed that PDK inhibition could ameliorate hemodynamic parameters, but outcomes varied, with great heterogeneity in patient response. The advantage of transforming metabolic-targeted drugs into clinical strategies remains to be determined.

A previous study [85] observed that a metabolic shift from mitochondrial oxidative phosphorylation to enhanced aerobic glycolysis in the pathogenesis of PAH. TGF- $\beta$ /BMPR2 and NOTCH/AMPK-AKT are currently known to be involved in the malignant proliferation of PAH PASMCs. Endothelial AMP-activated protein kinase (AMPK) plays a vital role in cardiovascular homeostasis. The molecular mechanisms underlying this phenomenon remain unclear. Recently, it has been found [86] that alpha-enolase regulates the malignant phenotype of PASMCs via the AMPK-AKT pathway. The results of that study also found that ENO1 levels were enhanced in PAH patients and hypoxic pulmonary hypertension rodent models. Pharmacological inhibition of ENO1 regulates metabolic pathways from mitochondrial respiration to glycolysis and reverses the hypoxia-induced metabolic shift in PASMCs and HPH models. One study shows that endothelial-specific AMPK-knockout $\left(\mathrm{eAMPK}^{-1}\right)$ mice exhibit accelerated PAH development accompanied by elevated growth factors and enhanced proliferation of PASMCs when exposed to hypoxia [87, 88]. Endothelial AMPK may be a novel protective therapeutic target for the treatment of PAH. Metformin, a multifunctional aromatase inhibitor and AMPK activator, has been shown to slow the exacerbation of PAH in sugen5416-hypoxia (SuHx) rats [89]. A phase II 12-week clinical trial investigating the function of metformin is in progress (NCT03617458). However, other studies uncovered the controversial role of AMPK signaling in PAH [90, 91], suggesting that the preferentially beneficial function of metformin therapy may be restricted to PAH associated with metabolic syndrome.

Imatinib is a selective tyrosine kinase inhibitor (TKI) that inhibits the activation of platelet-derived growth factor receptor (PDGFR), which is highly expressed in patients with $\mathrm{PAH}$ and is considered one of the exacerbating factors of disease progression $[92,93]$. The IMPRES (Imatinib in Pulmonary Arterial Hypertension) study [94, 95], a randomized efficacy study, found that imatinib could improve exercise capacity and hemodynamics among PAH patients inadequately responsive to 2-3 PAH-specific therapies (ClinicalTrials. gov identifier: NCT01392495). However, the severe adverse effects led to the termination of the clinical trial. Lacking target selectivity brings about significant side effects, such as subdural hematoma, along with a high discontinuation rate, which limits the utility of PAH treatment. Pulmonary veno-occlusive disease and/or pulmonary capillary hemangiomatosis $(\mathrm{PVOD} / \mathrm{PCH})$ are categorized as group 1 pulmonary hypertension, with no effective medical therapy except for lung transplantation. Recently, a small observational study [96] found that imatinib improved survival time and enhanced exercise capacity in patients with PVOD/PCH and may function as a bridge therapy to lung transplantation.

It is worth mentioning that dasatinib, another BCRABL tyrosine kinase inhibitor, causes pulmonary vascular damage and increased susceptibility to pulmonary hypertension by inducing PAEC apoptosis and mitochondrial ROS production in a dose-dependent manner, whereas imatinib does not [97]. This intriguing phenomenon suggests that studying the metabolism of $\mathrm{PAH}$ pathophysiology is useful for understanding its effects and drug toxicity and providing a proof of concept for promising therapeutic options.

\subsection{Oxidative stress}

Drugs targeting oxidative stress for PAH treatment, such as methods targeting apoptosis signal-regulating kinase 1 and mitochondrial ROS production, are being explored $[98,99]$. A preclinical study found [100] that an ASK1 inhibitor could halt the progression of pulmonary vascular and RV remodeling in murine PAH models. Nuclear factor erythroid 2-related factor 2 (Nrf2), another redoxregulated transcription factor, plays a key role in the redox homeostatic gene regulatory network. It can increase cytoprotectiveness, induce antioxidant enzymes/proteins, and protect against cardiopulmonary alterations caused by oxidative stress. A study found [101] that Nrf2-deficient transgenic mice developed more deteriorative RVF than WT mice, whereas Nrf2 activators attenuated RVF and pulmonary vascular remodeling.

A recent study found [102] that dimethyl fumarate (DMF), a nuclear factor erythroid 2-related factor 2 (Nrf2) activator, was effective in the sugen-hypoxia experimental PH model. DMF ameliorated the development of pulmonary hypertension and reversed hemodynamic changes in $\mathrm{PH}$ mice and exerted its antiinflammatory effects by reducing oxidative stress and directly targeting the NF- $\kappa B$ signaling pathway through covalent modification of $\mathrm{p} 65$. A phase I study among SSc- 
PAH patients is in progress (ClinicalTrials.gov identifier: NCT02981082). In 2013, the US Food and Drug Administration (FDA) approved DMF for the treatment of relapsing-remitting multiple sclerosis (RRMS) [103, 104].

Another Nrf2 pathway-activating agent, bardoxolone methyl, which was reported to decrease the production of toxic reactive oxygen species (ROS), seems to be effective in PH [105]. Another study [106] identified a novel hybridization with isosorbide 5-mononitrate and bardoxolone methyl that attenuated right ventricular hypertrophy and vascular muscularization in MCTinduced PAH rats. A diverse combination of multiple pathway inhibitions in pulmonary vascular remodeling makes it possible to find novel promising pharmacological therapeutic options. A phase III doubleblind, randomized, placebo-controlled trial among CTD$\mathrm{PAH}$ patients is in the patient recruitment stage (ClinicalTrials.gov identifier: NCT02657356).

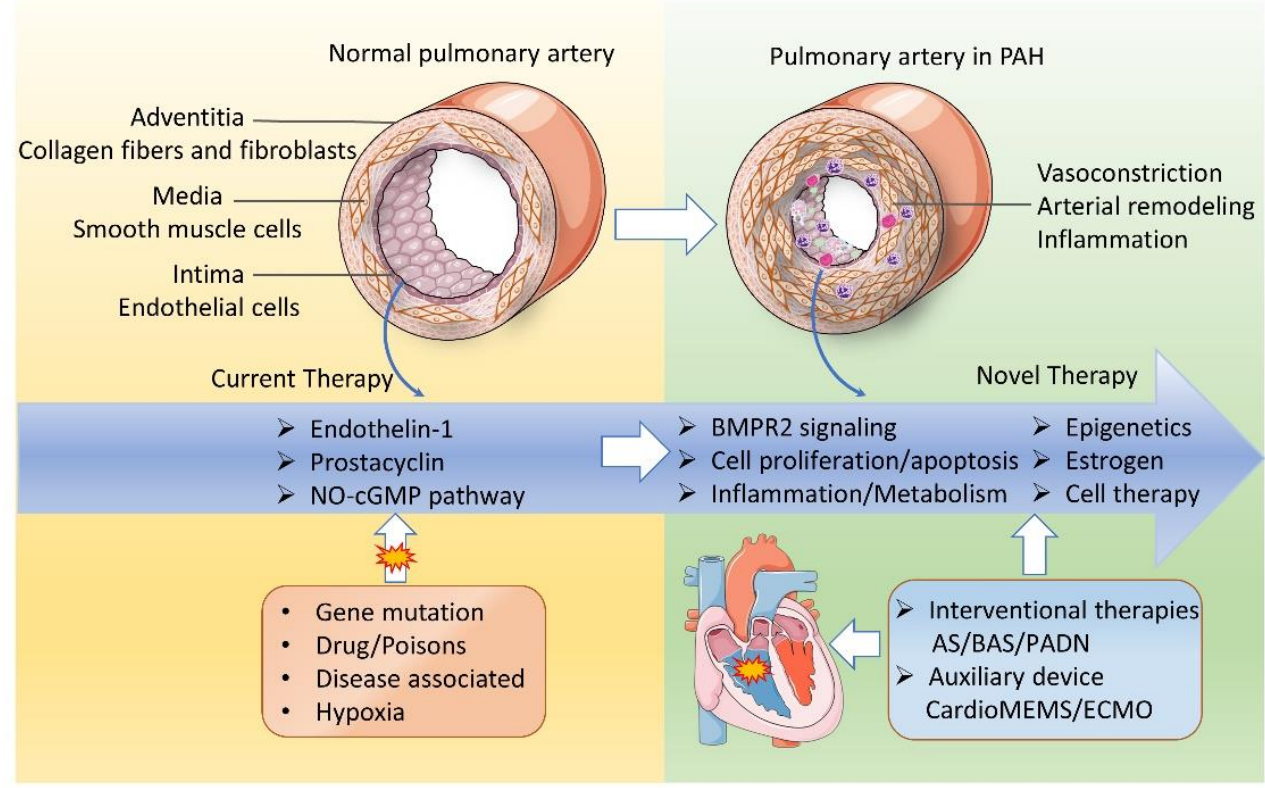

Figure 2. Pathobiology of PAH and potential therapeutic targets. Pathological mechanisms and potential therapeutic targets of PAH. The pulmonary artery wall consists of three structural layers, including the adventitia, media, and intima. Various pathogenic factors, such as gene mutations, drugs/poisons, and hypoxia, can induce pulmonary arteriole vascular vasoconstriction, characterized by luminal stenosis, endothelial dysfunction, inflammation, infiltration, etc., ultimately causing RHF. The endothelin-1, prostacyclin, and nitric oxide pathways have been targeted in clinical practice and are three pivotal pathways approved in PAH management. Potential therapeutic targets are emerging as the pathobiology of PAH is revealed. AS: atrial septostomy; BAS: balloon atrial septostomy; PADN: pulmonary artery denervation; ECMO: extracorporeal membrane oxygenation.

\section{Other potential therapies}

PAH remains a chronic progressive and irreversible disease that eventually results in RVF or death. Lung transplantation is the only final effective option for latestage PAH and patients classified as New York Heart Association (NYHA) functional class other than combined treatment. Artificial organ support and other potential adjuvant therapy options are pivotal for the treatment strategy as well. Assisting machines and devices have been invested to support the failing right ventricle, including extracorporeal membrane oxygenation (ECMO). Pumpless membrane oxygenators inserted between the pulmonary artery and the pulmonary veins or left atrium (PA-LA) and CardioMEMS are also an alternative therapeutic option [107, 108]. At the same time, it is important to maintain fluid management, supplementary oxygen therapy, and intensive care for PAH patients with RVF. Fig. 2 summarizes the pathobiology of PAH and potential therapeutic targets.

\subsection{Cell therapy}

Induced pluripotent stem cells (iPSCs) from skin fibroblasts of PAH patients provide new insight into the molecular mechanism and reprogramming in BMPR2 mutation carriers and PAH patients for individualized therapy [109]. The Pulmonary Hypertension and 
Angiogenic Cell Therapy (PHACeT) trial [110] is a phase I, dose-escalation study investigating the tolerability of endothelial progenitor cells overexpressing endothelial nitric oxide synthase via plasmid DNA in 7 patients with IPAH. In the study, gene-enhanced EPCs were injected into the patients' blood stream through the central vein via a Swan-Ganz catheter. No improvement in pulmonary hemodynamics was observed in the short term other than total pulmonary resistance, so further investigation is needed (NCT00469027). These studies using cell therapy are important for addressing the controversial question of the feasibility of patient-derived cellular phenotypes of PAH and for exploring the prospects of new treatment advances, such as using pulmonary organoids for drug screening in diverse conditions. These studies further promote a better understanding of rare pulmonary vascular diseases.

\subsection{Auxiliary devices}

CardioMEMS: The mortality of severe PAH with RHF is high. Are there any supporting devices available for PAH patients with decompensated RHF in addition to conventional therapy? The CHAMPION trial [111] found that maintaining pulmonary arterial pressure at a range of 10-25 mmHg in heart failure using CardioMEMS was promising. This study also found that the rehospitalization rate of HFrEF patients was reduced by $50 \%$ over a duration of 17.6 years. However, the increased adverse effects reported, such as injury of the pulmonary artery and hemoptysis, should be addressed by improving the inclusion criteria and operation technology to reduce the incidence of complications in the future.

Extracorporeal membrane oxygenation (ECMO): Patients will be recommended to the heart-lung transplant (HLTx) center for further treatment if they are defined as intermediate or high risk. ECMO is suggested for PAH patients after lung transplantation to minimize primary graft dysfunction or for patients with advanced PAH to prepare them for lung transplantation. A small-sample study [112] found that the 1-year survival rates of severe $\mathrm{PH}$ after lung transplantation exceeded 96\%. However, evidence showed that immediate perioperative transplant survival was poor compared with that in other conditions. Implanted pumpless membrane oxygenators between the pulmonary artery and the pulmonary veins or left atrium (PA-LA) are another frequently used method to support the right ventricle.

\subsection{Interventional therapies}

For patients who are ineligible for lung transplantation, an extracorporeal life support (ECLS) strategy may be administered as an alternative therapy to help patients endure imminent conditions before transplantation [113]. The trans-catheter potts shunt [114] may be an appropriate option to decrease the load returning to the right side of the heart and thus support cardiopulmonary function. Other interventional therapies, such as atrial septostomy (AS) and balloon atrial septostomy (BAS), can be attempted only to palliate and bridge the interval to lung transplant and only in experienced heart centers.

Pulmonary artery denervation (PADN) is a novel technique that provides a promising therapeutic option for patients with $\mathrm{PAH}$, as it can inhibit sympathetic stimulation [115]. A clinical trial is in progress (NCT02284737) to observe the changes in 6MWD and in hemodynamic responses.

\section{Conclusion}

$\mathrm{PAH}$ remains a life-threatening disease with a poor diagnosis despite the emergence of vasodilator therapies. Potential therapeutic targets of PAH are emerging with the growing understanding of pathological mechanisms. Therapeutic targets that focus on BMPR2 mutations, apoptosis of PAECs and proliferation of PASMCs, inflammation, epigenetic modifications, and metabolic pathways will attract increasing attention in the near future. However, potential therapies require further investigation before implementation. Not every drug has the same efficacy for all patients. Different treatment approaches may potentially improve overall survival depending upon the distinct pathogenesis of the disease. The ongoing preclinical trials might offer new insight into therapeutic interventions in patients with $\mathrm{PAH}$ and additional rare diseases.

\section{Acknowledgments}

This study was funded by the National Key Research and Development Program of China (grant number 2016YFC0901500) and Beijing Natural Science Foundation (grant number 7192155).

\section{Conflict of interest}

The authors declare that they have no conflicts of interest.

\section{References}

[1] Schermuly RT, Ghofrani HA, Wilkins MR, Grimminger F (2011). Mechanisms of disease: pulmonary arterial hypertension. Nat Rev Cardiol, 8:443-455.

Galie N, Humbert M, Vachiery JL, Gibbs S, Lang I, Torbicki A, et al. (2015). 2015 ESC/ERS Guidelines for the diagnosis and treatment of pulmonary hypertension: The Joint Task Force for the Diagnosis and Treatment of Pulmonary Hypertension of the European Society of Cardiology (ESC) and the 
European Respiratory Society (ERS): Endorsed by: Association for European Paediatric and Congenital Cardiology (AEPC), International Society for Heart and Lung Transplantation (ISHLT). Eur Respir J, 46:903-975.

[3] Simonneau G, Gatzoulis MA, Adatia I, Celermajer D, Denton C, Ghofrani A, et al. (2013). Updated Clinical Classification of Pulmonary Hypertension. Journal of the American College of Cardiology, 62:D34-D41.

[4] Condliffe R, Kiely DG, Peacock AJ, Corris PA, Gibbs JS, Vrapi F, et al. (2009). Connective tissue diseaseassociated pulmonary arterial hypertension in the modern treatment era. Am J Respir Crit Care Med, 179:151-157.

[5] Peacock AJ, Murphy NF, McMurray JJ, Caballero L, Stewart S (2007). An epidemiological study of pulmonary arterial hypertension. Eur Respir J, 30:104109.

[6] Ghofrani HA, Grimminger F, Grunig E, Huang Y, Jansa P, Jing ZC, et al. (2016). Predictors of long-term outcomes in patients treated with riociguat for pulmonary arterial hypertension: data from the PATENT-2 open-label, randomised, long-term extension trial. Lancet Respir Med, 4:361-371.

[7] Hachulla E, Jais X, Cinquetti G, Clerson P, Rottat L, Launay D, et al. (2018). Pulmonary Arterial Hypertension Associated With Systemic Lupus Erythematosus: Results From the French Pulmonary Hypertension Registry. Chest, 153:143-151.

[8] D'Alonzo GE, Barst RJ, Ayres SM, Bergofsky EH, Brundage BH, Detre KM, et al. (1991). Survival in patients with primary pulmonary hypertension. Results from a national prospective registry. Ann Intern Med, 115:343-349.

[9] Humbert M, Sitbon O, Chaouat A, Bertocchi M, Habib G, Gressin V, et al. (2006). Pulmonary arterial hypertension in France: results from a national registry. Am J Respir Crit Care Med, 173:1023-1030.

[10] Klinger JR, Elliott CG, Levine DJ, Bossone E, Duvall L, Fagan K, et al. (2019). Therapy for Pulmonary Arterial Hypertension in Adults: Update of the CHEST Guideline and Expert Panel Report. Chest, 155:565586.

[11] Frost A, Badesch D, Gibbs JSR, Gopalan D, Khanna D, Manes A, et al. (2019). Diagnosis of pulmonary hypertension. Eur Respir J, 53.

[12] Hoeper M, McLaughlin V, Barberá J, Frost A, Ghofrani H, Peacock A, et al. (2016). Initial combination therapy with ambrisentan and tadalafil and mortality in patients with pulmonary arterial hypertension: a secondary analysis of the results from the randomised, controlled AMBITION study. Lancet Respir Med, 4:894-901.

[13] Simonneau G, Montani D, Celermajer DS, Denton CP, Gatzoulis MA, Krowka M, et al. (2019). Haemodynamic definitions and updated clinical classification of pulmonary hypertension. Eur Respir J, 53.

[14] Galambos C, Mullen MP, Shieh JT, Schwerk N, Kielt MJ, Ullmann N, et al. (2019). Phenotype characterisation of mutation and deletion carriers with neonatal and paediatric pulmonary hypertension. The European respiratory journal, 54:undefined.

[15] Wang X, Lian T, Jiang X, Liu S, Li S, Jiang R, et al. (2019). Germline mutation causes idiopathic pulmonary arterial hypertension. The European respiratory journal, 53 .

[16] Long L, Ormiston ML, Yang X, Southwood M, Graf S, Machado RD, et al. (2015). Selective enhancement of endothelial BMPR-II with BMP9 reverses pulmonary arterial hypertension. Nat Med, 21:777785.

[17] Morine KJ, Qiao X, York S, Natov PS, Paruchuri V, Zhang Y, et al. (2018). Bone Morphogenetic Protein 9 Reduces Cardiac Fibrosis and Improves Cardiac Function in Heart Failure. Circulation, 138:513-526.

[18] Tu L, Desroches-Castan A, Mallet C, Guyon L, Cumont A, Phan C, et al. (2019). Selective BMP-9 Inhibition Partially Protects Against Experimental Pulmonary Hypertension. Circ Res, 124:846-855.

[19] Evans JD, Girerd B, Montani D, Wang XJ, Galie N, Austin ED, et al. (2016). BMPR2 mutations and survival in pulmonary arterial hypertension: an individual participant data meta-analysis. Lancet Respir Med, 4:129-137.

[20] Hong JH, Lee GT, Lee JH, Kwon SJ, Park SH, Kim SJ, et al. (2009). Effect of bone morphogenetic protein-6 on macrophages. Immunology, 128:e442-450.

[21] Sawada H, Saito T, Nickel NP, Alastalo TP, Glotzbach JP, Chan R, et al. (2014). Reduced BMPR2 expression induces GM-CSF translation and macrophage recruitment in humans and mice to exacerbate pulmonary hypertension. J Exp Med, 211:263-280.

[22] Pickup MW, Hover LD, Polikowsky ER, Chytil A, Gorska AE, Novitskiy SV, et al. (2015). BMPR2 loss in fibroblasts promotes mammary carcinoma metastasis via increased inflammation. Mol Oncol, 9:179-191.

[23] van der Bruggen CE, Happe CM, Dorfmuller P, Trip P, Spruijt OA, Rol N, et al. (2016). Bone Morphogenetic Protein Receptor Type 2 Mutation in Pulmonary Arterial Hypertension: A View on the Right Ventricle. Circulation, 133:1747-1760.

[24] Hemnes AR, Brittain EL, Trammell AW, Fessel JP, Austin ED, Penner N, et al. (2014). Evidence for right ventricular lipotoxicity in heritable pulmonary arterial hypertension. Am J Respir Crit Care Med, 189:325334.

[25] Cogan JD, Pauciulo MW, Batchman AP, Prince MA, Robbins IM, Hedges LK, et al. (2006). High frequency of BMPR2 exonic deletions/duplications in familial pulmonary arterial hypertension. Am J Respir Crit Care Med, 174:590-598.

[26] Morrell NW, Aldred MA, Chung WK, Elliott CG, Nichols WC, Soubrier F, et al. (2018). Genetics and genomics of pulmonary arterial hypertension. Eur Respir J.

[27] Newman JH, Wheeler L, Lane KB, Loyd E, Gaddipati R, Phillips JA, 3rd, et al. (2001). Mutation in the gene for bone morphogenetic protein receptor II as a cause 
of primary pulmonary hypertension in a large kindred. N Engl J Med, 345:319-324.

[28] Liu D, Wu WH, Mao YM, Yuan P, Zhang R, Ju FL, et al. (2012). BMPR2 mutations influence phenotype more obviously in male patients with pulmonary arterial hypertension. Circ Cardiovasc Genet, 5:511518.

[29] Machado RD, Aldred MA, James V, Harrison RE, Patel B, Schwalbe EC, et al. (2006). Mutations of the TGF-beta type II receptor BMPR2 in pulmonary arterial hypertension. Hum Mutat, 27:121-132.

[30] Spiekerkoetter E, Sung YK, Sudheendra D, Bill M, Aldred MA, van de Veerdonk MC, et al. (2015). LowDose FK506 (Tacrolimus) in End-Stage Pulmonary Arterial Hypertension. Am J Respir Crit Care Med, 192:254-257.

[31] Spiekerkoetter E, Tian X, Cai J, Hopper RK, Sudheendra D, Li CG, et al. (2013). FK506 activates BMPR2, rescues endothelial dysfunction, and reverses pulmonary hypertension. J Clin Invest, 123:36003613.

[32] Takeda Y, Miyamori I, Furukawa K, Inaba S, Mabuchi H (1999). Mechanisms of FK 506-induced hypertension in the rat. Hypertension, 33:130-136.

[33] Spiekerkoetter E, Sung YK, Sudheendra D, Scott V, Del Rosario P, Bill M, et al. (2017). Randomised placebo-controlled safety and tolerability trial of FK506 (tacrolimus) for pulmonary arterial hypertension. The European respiratory journal, 50:undefined.

[34] Kurosawa R, Satoh K, Kikuchi N, Kikuchi H, Saigusa $\mathrm{D}$, Al-Mamun ME, et al. (2019). Identification of Celastramycin as a Novel Therapeutic Agent for Pulmonary Arterial Hypertension-High-throughput Screening of 5,562 Compounds. Circ Res.

[35] Huertas A, Phan C, Bordenave J, Tu L, Thuillet R, Le Hiress M, et al. (2016). Regulatory T Cell Dysfunction in Idiopathic, Heritable and Connective TissueAssociated Pulmonary Arterial Hypertension. Chest, 149:1482-1493.

[36] Meng X, Yang J, Dong M, Zhang K, Tu E, Gao Q, et al. (2016). Regulatory $\mathrm{T}$ cells in cardiovascular diseases. Nature reviews. Cardiology, 13:167-179.

[37] Tamosiuniene R, Manouvakhova O, Mesange P, Saito T, Qian J, Sanyal M, et al. (2018). Dominant Role for Regulatory $\mathrm{T}$ Cells in Protecting Females Against Pulmonary Hypertension. Circulation research, 122:1689-1702.

[38] Pugliese SC, Poth JM, Fini MA, Olschewski A, El Kasmi KC, Stenmark KR (2015). The role of inflammation in hypoxic pulmonary hypertension: from cellular mechanisms to clinical phenotypes. Am J Physiol Lung Cell Mol Physiol, 308:L229-252.

[39] Kuebler WM, Bonnet S, Tabuchi A (2018). Inflammation and autoimmunity in pulmonary hypertension: is there a role for endothelial adhesion molecules? (2017 Grover Conference Series). Pulm Circ, 8:2045893218757596.

[40] Edwards AL, Gunningham SP, Clare GC, Hayman MW, Smith M, Frampton CM, et al. (2013).
Professional killer cell deficiencies and decreased survival in pulmonary arterial hypertension. Respirology, 18:1271-1277.

[41] Ormiston ML, Chang C, Long LL, Soon E, Jones D, Machado R, et al. (2012). Impaired natural killer cell phenotype and function in idiopathic and heritable pulmonary arterial hypertension. Circulation, 126:1099-1109.

[42] Rabinovitch M, Guignabert C, Humbert M, Nicolls MR (2014). Inflammation and immunity in the pathogenesis of pulmonary arterial hypertension. Circ Res, 115:165-175.

[43] Huertas A, Phan C, Bordenave J, Tu L, Thuillet R, Le Hiress M, et al. (2016). Regulatory T Cell Dysfunction in Idiopathic, Heritable and Connective TissueAssociated Pulmonary Arterial Hypertension. Chest, 149:1482-1493.

[44] Tamosiuniene R, Tian W, Dhillon G, Wang L, Sung YK, Gera L, et al. (2011). Regulatory T cells limit vascular endothelial injury and prevent pulmonary hypertension. Circ Res, 109:867-879.

[45] Abid S, Marcos E, Parpaleix A, Amsellem V, Breau M, Houssaini A, et al. (2019). CCR2/CCR5-Mediated Macrophage-Smooth Muscle Cell Crosstalk in Pulmonary Hypertension. The European respiratory journal, undefined:undefined.

[46] Salah SM, Meisenheimer JD, Rao R, Peda JD, Wallace DP, Foster D, et al. (2019). MCP-1 promotes detrimental cardiac physiology, pulmonary edema, and death in the model of polycystic kidney disease. American journal of physiology. Renal physiology, 317:F343-F360.

[47] Yasuoka H, Shirai Y, Tamura Y, Takeuchi T, Kuwana M (2018). Predictors of Favorable Responses to Immunosuppressive Treatment in Pulmonary Arterial Hypertension Associated With Connective Tissue Disease. Circ J, 82:546-554.

[48] Sun F, Lei Y, Wu W, Guo L, Wang K, Chen Z, et al. (2019). Two distinct clinical phenotypes of pulmonary arterial hypertension secondary to systemic lupus erythematosus. Ann Rheum Dis, 78:148-150.

[49] Qian J, Li M, Zhao J, Wang Q, Tian Z, Zeng X (2018). Inflammation in SLE-PAH: good news or not? Annals of the Rheumatic Diseases: annrheumdis-2018214605.

[50] Tamura Y, Phan C, Tu L, Le Hiress M, Thuillet R, Jutant EM, et al. (2018). Ectopic upregulation of membrane-bound IL6R drives vascular remodeling in pulmonary arterial hypertension. J Clin Invest, 128:1956-1970.

[51] Pickworth J, Rothman A, Iremonger J, Casbolt H, Hopkinson K, Hickey PM, et al. (2017). Differential IL-1 signaling induced by BMPR2 deficiency drives pulmonary vascular remodeling. Pulm Circ, 7:768776.

[52] Soon E, Holmes AM, Treacy CM, Doughty NJ, Southgate L, Machado RD, et al. (2010). Elevated levels of inflammatory cytokines predict survival in idiopathic and familial pulmonary arterial hypertension. Circulation, 122:920-927. 
[53] Voelkel NF, Tuder RM, Bridges J, Arend WP (1994). Interleukin-1 receptor antagonist treatment reduces pulmonary hypertension generated in rats by monocrotaline. Am J Respir Cell Mol Biol, 11:664675.

[54] Furuya Y, Satoh T, Kuwana M (2010). Interleukin-6 as a potential therapeutic target for pulmonary arterial hypertension. Int J Rheumatol, 2010:720305.

[55] Sanayama Y, Ikeda K, Saito Y, Kagami S, Yamagata M, Furuta S, et al. (2014). Prediction of therapeutic responses to tocilizumab in patients with rheumatoid arthritis: biomarkers identified by analysis of gene expression in peripheral blood mononuclear cells using genome-wide DNA microarray. Arthritis Rheumatol, 66:1421-1431.

[56] Pullamsetti SS, Seeger W, Savai R (2018). Classical IL-6 signaling: a promising therapeutic target for pulmonary arterial hypertension. J Clin Invest, 128:1720-1723.

[57] Humbert M, Monti G, Brenot F, Sitbon O, Portier A, Grangeot-Keros L, et al. (1995). Increased interleukin1 and interleukin-6 serum concentrations in severe primary pulmonary hypertension. Am J Respir Crit Care Med, 151:1628-1631.

[58] Parpaleix A, Amsellem V, Houssaini A, Abid S, Breau $\mathrm{M}$, Marcos E, et al. (2016). Role of interleukin-1 receptor $1 / \mathrm{MyD} 88$ signalling in the development and progression of pulmonary hypertension. Eur Respir J, 48:470-483.

[59] Trankle CR, Canada JM, Kadariya D, Markley R, De Chazal HM, Pinson J, et al. (2019). IL-1 Blockade Reduces Inflammation in Pulmonary Arterial Hypertension and Right Ventricular Failure: A SingleArm, Open-Label, Phase IB/II Pilot Study. American Journal of Respiratory and Critical Care Medicine, 199:381-384.

[60] Van Tassell BW, Canada J, Carbone S, Trankle C, Buckley L, Oddi Erdle C, et al. (2017). Interleukin-1 Blockade in Recently Decompensated Systolic Heart Failure: Results From REDHART (Recently Decompensated Heart Failure Anakinra Response Trial). Circ Heart Fail, 10.

[61] Hennigan S, Channick RN, Silverman GJ (2008). Rituximab treatment of pulmonary arterial hypertension associated with systemic lupus erythematosus: a case report. Lupus, 17:754-756.

[62] Wang L, Liu J, Wang W, Qi X, Wang Y, Tian B, et al. (2019). Targeting IL-17 attenuates hypoxia-induced pulmonary hypertension through downregulation of beta-catenin. Thorax, 74:564-578.

[63] Hurst LA, Dunmore BJ, Long L, Crosby A, Al-Lamki $\mathrm{R}$, Deighton J, et al. (2017). TNF $\alpha$ drives pulmonary arterial hypertension by suppressing the BMP type-II receptor and altering NOTCH signalling. communications, 8:14079.

[64] Berger SL, Kouzarides T, Shiekhattar R, Shilatifard A (2009). An operational definition of epigenetics. Genes Dev, 23:781-783.

[65] Kim GH, Ryan JJ, Archer SL (2013). The role of redox signaling in epigenetics and cardiovascular disease.
Antioxid Redox Signal, 18:1920-1936.

[66] Zhao L, Chen CN, Hajji N, Oliver E, Cotroneo E, Wharton J, et al. (2012). Histone deacetylation inhibition in pulmonary hypertension: therapeutic potential of valproic acid and suberoylanilide hydroxamic acid. Circulation, 126:455-467.

[67] Bogaard HJ, Mizuno S, Hussaini AA, Toldo S, Abbate A, Kraskauskas D, et al. (2011). Suppression of histone deacetylases worsens right ventricular dysfunction after pulmonary artery banding in rats. Am J Respir Crit Care Med, 183:1402-1410.

[68] Dai Z, Zhao YY (2019). BET in Pulmonary Arterial Hypertension: Exploration of BET Inhibitors to Reverse Vascular Remodeling. Am J Respir Crit Care Med.

[69] Van der Feen DE, Kurakula K, Tremblay E, Boucherat O, Bossers GP, Szulcek R, et al. (2019). Multicenter Preclinical Validation of BET Inhibition for the Treatment of Pulmonary Arterial Hypertension. Am J Respir Crit Care Med.

[70] Yeager ME, Halley GR, Golpon HA, Voelkel NF, Tuder RM (2001). Microsatellite instability of endothelial cell growth and apoptosis genes within plexiform lesions in primary pulmonary hypertension. Circ Res, 88:E2-e11.

[71] Ranchoux B, Meloche J, Paulin R, Boucherat O, Provencher S, Bonnet S (2016). DNA Damage and Pulmonary Hypertension. Int J Mol Sci, 17.

[72] Federici C, Drake KM, Rigelsky CM, McNelly LN, Meade SL, Comhair SA, et al. (2015). Increased Mutagen Sensitivity and DNA Damage in Pulmonary Arterial Hypertension. Am J Respir Crit Care Med, 192:219-228.

[73] Meloche J, Pflieger A, Vaillancourt M, Paulin R, Potus F, Zervopoulos S, et al. (2014). Role for DNA damage signaling in pulmonary arterial hypertension. Circulation, 129:786-797.

[74] Badesch DB, Raskob GE, Elliott CG, Krichman AM, Farber HW, Frost AE, et al. (2010). Pulmonary arterial hypertension: baseline characteristics from the REVEAL Registry. Chest, 137:376-387.

[75] Lahm T, Albrecht M, Fisher AJ, Selej M, Patel NG, Brown JA, et al. (2012). 17beta-Estradiol attenuates hypoxic pulmonary hypertension via estrogen receptor-mediated effects. Am J Respir Crit Care Med, 185:965-980.

[76] Chen X, Austin ED, Talati M, Fessel JP, Farber-Eger $\mathrm{EH}$, Brittain EL, et al. (2017). Oestrogen inhibition reverses pulmonary arterial hypertension and associated metabolic defects. Eur Respir J, 50.

[77] Jacobs W, van de Veerdonk MC, Trip P, de Man F, Heymans MW, Marcus JT, et al. (2014). The right ventricle explains sex differences in survival in idiopathic pulmonary arterial hypertension. Chest, 145:1230-1236.

[78] Baird GL, Archer-Chicko C, Barr RG, Bluemke DA, Foderaro AE, Fritz JS, et al. (2018). Lower DHEA-S levels predict disease and worse outcomes in postmenopausal women with idiopathic, connective tissue disease- and congenital heart disease-associated 
pulmonary arterial hypertension. Eur Respir J, 51 .

[79] Ventetuolo CE, Baird GL, Barr RG, Bluemke DA, Fritz JS, Hill NS, et al. (2016). Higher Estradiol and Lower Dehydroepiandrosterone-Sulfate Levels Are Associated with Pulmonary Arterial Hypertension in Men. Am J Respir Crit Care Med, 193:1168-1175.

[80] Kawut SM, Lima JA, Barr RG, Chahal H, Jain A, Tandri H, et al. (2011). Sex and race differences in right ventricular structure and function: the multiethnic study of atherosclerosis-right ventricle study. Circulation, 123:2542-2551.

[81] Mair KM, Yang XD, Long L, White K, Wallace E, Ewart MA, et al. (2015). Sex affects bone morphogenetic protein type II receptor signaling in pulmonary artery smooth muscle cells. Am J Respir Crit Care Med, 191:693-703.

[82] Mair KM, Harvey KY, Henry AD, Hillyard DZ, Nilsen M, MacLean MR (2019). Obesity alters oestrogen metabolism and contributes to pulmonary arterial hypertension. Eur Respir J, 53.

[83] Kawut SM, Archer-Chicko CL, DeMichele A, Fritz JS, Klinger JR, Ky B, et al. (2017). Anastrozole in Pulmonary Arterial Hypertension. A Randomized, Double-Blind, Placebo-controlled Trial. Am J Respir Crit Care Med, 195:360-368.

[84] Michelakis ED, Gurtu V, Webster L, Barnes G, Watson G, Howard L, et al. (2017). Inhibition of pyruvate dehydrogenase kinase improves pulmonary arterial hypertension in genetically susceptible patients. Science translational medicine, 9:undefined.

[85] Sutendra G, Michelakis ED (2014). The metabolic basis of pulmonary arterial hypertension. Cell Metab, 19:558-573.

[86] Zhou Q, Chen J, Rexius-Hall ML, Rehman J, Zhou G (2018). Alpha-enolase regulates the malignant phenotype of pulmonary artery smooth muscle cells via the AMPK-Akt pathway.\%A Dai J. Nature communications, 9:3850.

[87] Hansmann G, Wagner RA, Schellong S, Perez VA, Urashima T, Wang L, et al. (2007). Pulmonary arterial hypertension is linked to insulin resistance and reversed by peroxisome proliferator-activated receptor-gamma activation. Circulation, 115:12751284.

[88] Omura J, Satoh K, Kikuchi N, Satoh T, Kurosawa R, Nogi M, et al. (2016). Protective Roles of Endothelial AMP-Activated Protein Kinase Against HypoxiaInduced Pulmonary Hypertension in Mice. Circulation research, 119:197-209.

[89] Dean A, Nilsen M, Loughlin L, Salt IP, MacLean MR (2016). Metformin Reverses Development of Pulmonary Hypertension via Aromatase Inhibition. Hypertension, 68:446-454.

[90] Goncharov DA, Goncharova EA, Tofovic SP, Hu J, Baust JJ, Pena AZ, et al. (2018). Metformin Therapy for Pulmonary Hypertension Associated with Heart Failure with Preserved Ejection Fraction versus Pulmonary Arterial Hypertension. Am J Respir Crit Care Med, 198:681-684.

[91] Lai YC, Tabima DM, Dube JJ, Hughan KS,
Vanderpool RR, Goncharov DA, et al. (2016). SIRT3AMP-Activated Protein Kinase Activation by Nitrite and Metformin Improves Hyperglycemia and Normalizes Pulmonary Hypertension Associated With Heart Failure With Preserved Ejection Fraction. Circulation, 133:717-731.

[92] Schermuly RT, Dony E, Ghofrani HA, Pullamsetti S, Savai R, Roth M, et al. (2005). Reversal of experimental pulmonary hypertension by PDGF inhibition. J Clin Invest, 115:2811-2821.

[93] Ciuclan L, Hussey MJ, Burton V, Good R, Duggan N, Beach S, et al. (2013). Imatinib attenuates hypoxiainduced pulmonary arterial hypertension pathology via reduction in 5-hydroxytryptamine through inhibition of tryptophan hydroxylase 1 expression. American journal of respiratory and critical care medicine, 187:78-89.

[94] Hoeper MM, Barst RJ, Bourge RC, Feldman J, Frost AE, Galie N, et al. (2013). Imatinib mesylate as addon therapy for pulmonary arterial hypertension: results of the randomized IMPRES study. Circulation, 127:1128-1138.

[95] Frost AE, Barst RJ, Hoeper MM, Chang HJ, Frantz RP, Fukumoto Y, et al. (2015). Long-term safety and efficacy of imatinib in pulmonary arterial hypertension. J Heart Lung Transplant, 34:1366-1375.

[96] Ogawa A, Miyaji K, Matsubara H (2017). Efficacy and safety of long-term imatinib therapy for patients with pulmonary veno-occlusive disease and pulmonary capillary hemangiomatosis. Respir Med, 131:215-219.

[97] Guignabert C, Phan C, Seferian A, Huertas A, Tu L, Thuillet R, et al. (2016). Dasatinib induces lung vascular toxicity and predisposes to pulmonary hypertension. The Journal of clinical investigation, 126:3207-3218.

[98] Hansen T, Galougahi KK, Celermajer D, Rasko N, Tang O, Bubb KJ, et al. (2016). Oxidative and nitrosative signalling in pulmonary arterial hypertension Implications for development of novel therapies. Pharmacology \& Therapeutics, 165:50-62.

[99] MK C, SY C (2018). Mitochondrial metabolism in pulmonary hypertension: beyond mountains there are mountains. The Journal of clinical investigation, 128:3704-3715.

[100] Budas GR, Boehm M, Kojonazarov B, Viswanathan G, Tian X, Veeroju S, et al. (2018). ASK1 Inhibition Halts Disease Progression in Preclinical Models of Pulmonary Arterial Hypertension. American journal of respiratory and critical care medicine, 197:373-385.

[101] Eba S, Hoshikawa Y, Moriguchi T, Mitsuishi Y, Satoh H, Ishida K, et al. (2013). The nuclear factor erythroid 2-related factor 2 activator oltipraz attenuates chronic hypoxia-induced cardiopulmonary alterations in mice. Am J Respir Cell Mol Biol, 49:324-333.

[102] Grzegorzewska AP, Seta F, Han R, Czajka CA, Makino K, Stawski L, et al. (2017). Dimethyl Fumarate ameliorates pulmonary arterial hypertension and lung fibrosis by targeting multiple pathways. Scientific reports, 7:41605.

Hutchinson M, Fox RJ, Miller DH, Phillips JT, Kita M, 
Havrdova E, et al. (2013). Clinical efficacy of BG-12 (dimethyl fumarate) in patients with relapsingremitting multiple sclerosis: subgroup analyses of the CONFIRM study. J Neurol, 260:2286-2296.

[104] Fox RJ, Miller DH, Phillips JT, Hutchinson M, Havrdova E, Kita M, et al. (2012). Placebo-controlled phase 3 study of oral BG-12 or glatiramer in multiple sclerosis. N Engl J Med, 367:1087-1097.

[105] Lu HI, Huang TH, Sung PH, Chen YL, Chua S, Chai $\mathrm{HY}$, et al. (2016). Administration of antioxidant peptide SS-31 attenuates transverse aortic constriction-induced pulmonary arterial hypertension in mice. Acta Pharmacol Sin, 37:589-603.

[106] Cheng Y, Gong Y, Qian S, Mou Y, Li H, Chen X, et al. (2018). Identification of a Novel Hybridization from Isosorbide 5-Mononitrate and Bardoxolone Methyl with Dual Activities of Pulmonary Vasodilation and Vascular Remodeling Inhibition on Pulmonary Arterial Hypertension Rats. Journal of medicinal chemistry, 61:1474-1482.

[107] Hoeper MM, Benza RL, Corris P, de Perrot M, Fadel E, Keogh AM, et al. (2019). Intensive care, right ventricular support and lung transplantation in patients with pulmonary hypertension. European Respiratory Journal, 53.

[108] Machuca TN, de Perrot M (2015). Mechanical Support for the Failing Right Ventricle in Patients With Precapillary Pulmonary Hypertension. Circulation, 132:526-536.

[109] Gu M, Shao NY, Sa S, Li D, Termglinchan V, Ameen M, et al. (2017). Patient-Specific iPSC-Derived Endothelial Cells Uncover Pathways that Protect against Pulmonary Hypertension in BMPR2 Mutation Carriers. Cell Stem Cell, 20:490-504 e495.

[110] Granton J, Langleben D, Kutryk MB, Camack N, Galipeau J, Courtman DW, et al. (2015). Endothelial NO-Synthase Gene-Enhanced Progenitor Cell Therapy for Pulmonary Arterial Hypertension: The PHACeT Trial. Circ Res, 117:645-654.

[111] Abraham WT, Stevenson LW, Bourge RC, Lindenfeld JA, Bauman JG, Adamson PB (2016). Sustained efficacy of pulmonary artery pressure to guide adjustment of chronic heart failure therapy: complete follow-up results from the CHAMPION randomised trial. Lancet, 387:453-461.

[112] Tudorache I, Sommer W, Kuhn C, Wiesner O, Hadem J, Fuhner T, et al. (2015). Lung transplantation for severe pulmonary hypertension--awake extracorporeal membrane oxygenation for postoperative left ventricular remodelling. Transplantation, 99:451-458.

[113] Galie N, Humbert M, Vachiery JL, Gibbs S, Lang I, Torbicki A, et al. (2016). 2015 ESC/ERS Guidelines for the diagnosis and treatment of pulmonary hypertension: The Joint Task Force for the Diagnosis and Treatment of Pulmonary Hypertension of the European Society of Cardiology (ESC) and the European Respiratory Society (ERS): Endorsed by: Association for European Paediatric and Congenital Cardiology (AEPC), International Society for Heart and Lung Transplantation (ISHLT). Eur Heart J, 37:67-119.

[114] Bhamra-Ariza P, Keogh AM, Muller DWM (2014). Percutaneous interventional therapies for the treatment of patients with severe pulmonary hypertension. J Am Coll Cardiol, 63:611-618.

[115] Chen SL, Zhang FF, Xu J, Xie DJ, Zhou L, Nguyen T, et al. (2013). Pulmonary artery denervation to treat pulmonary arterial hypertension: the single-center, prospective, first-in-man PADN-1 study (first-in-man pulmonary artery denervation for treatment of pulmonary artery hypertension). J Am Coll Cardiol, 62:1092-1100.

[116] Trembath RC, Thomson JR, Machado RD, Morgan NV, Atkinson C, Winship I, et al. (2001). Clinical and molecular genetic features of pulmonary hypertension in patients with hereditary hemorrhagic telangiectasia. N Engl J Med, 345:325-334.

[117] Girerd B, Montani D, Coulet F, Sztrymf B, Yaici A, Jais X, et al. (2010). Clinical outcomes of pulmonary arterial hypertension in patients carrying an ACVRL1 (ALK1) mutation. Am J Respir Crit Care Med, 181:851-861.

[118] Chaouat A, Coulet F, Favre C, Simonneau G, Weitzenblum E, Soubrier F, et al. (2004). Endoglin germline mutation in a patient with hereditary haemorrhagic telangiectasia and dexfenfluramine associated pulmonary arterial hypertension. Thorax, 59:446-448.

[119] Graf S, Haimel M, Bleda M, Hadinnapola C, Southgate L, Li W, et al. (2018). Identification of rare sequence variation underlying heritable pulmonary arterial hypertension. Nat Commun, 9:1416.

[120] Ma L, Roman-Campos D, Austin ED, Eyries M, Sampson KS, Soubrier F, et al. (2013). A novel channelopathy in pulmonary arterial hypertension. $\mathrm{N}$ Engl J Med, 369:351-361.

[121] Montani D, Girerd B, Jais X, Levy M, Amar D, Savale L, et al. (2017). Clinical phenotypes and outcomes of heritable and sporadic pulmonary veno-occlusive disease: a population-based study. Lancet Respir Med, 5:125-134.

[122] Levy M, Eyries M, Szezepanski I, Ladouceur M, Nadaud S, Bonnet D, et al. (2016). Genetic analyses in a cohort of children with pulmonary hypertension. Eur Respir J, 48:1118-1126. 